\title{
Challenges to Development: The North- South Roundtable (NSRT) in perspective
}

\author{
KHADIJA HAQ
}

\begin{abstract}
Khadija Haq outlines the successes of the NSRT in setting the human centred international development agenda of the last decades. Within this context she also frames the major questions posed by the papers published here from the Tidewater NSRT meeting.
\end{abstract}

It is people and their work, it is the new ideas, the visions that begin to change society. I would say that we dare to be headstrong, that we will be dedicated, and that we will not cease until ideas that are represented here of world justice, of world community, of interdependence of our beautiful planet, will be realized.

(Barbara Ward, 1980)

\section{North-South Roundtable contributions to development dialogue}

For the last two eventful decades the NSRT has played a central role in shaping and influencing the global development dialogue. It has been at the cutting edge of many new global issues, challenges and initiatives. The stimulus for the first North-South Summit in Cancun, which was held in 1981, emerged from a concrete proposal in a 1980 NSRT session. The proposal for a South-South Commission which culminated in the Nyerere commission was launched by another NSRT session. The NSRT session on the theme of human development proposed a world summit on human development which eventually materialized as the World Social Summit in Copenhagen in 1995. Again a special session of the NSRT proposed that annual reports be prepared not just on the state of the world economy but on the state of the human condition. This seminal idea has culminated in the form of the annual Human Development Reports by the UNDP since 1990. And there are many other ideas still in the pipeline.

Even more influential than concrete proposals has been the professional and objective spirit of enquiry with which the NSRT sessions have approached global issues. The NSRT has come together not in any partisan spirit, nor in a 
spirit of confrontation. They have aimed to create a new and constructive intellectual synthesis towards a promising change in human understanding and dialogue, or to put it in the eloquent words of the NSRT founder and intellectual guide, Barbara Ward, at the inaugural session of the NSRT in Rome in 1978: so that NSRT deliberations 'could make a turning point in our understanding of planetary dilemmas'. It is in this spirit that the NSRT has continued to debate over the last two decades some of the most critical issues on the global agenda, with courage and uncompromising intellectual integrity - often sailing against the prevailing winds, often rejecting conventional wisdom, often daring to rethink and innovate.

Let us pay a sincere tribute to the pioneers who had the personal courage to guide us along the road: our first four chairpeople, Barbara Ward, Mahbub ul Haq, Maurice Strong and Richard Jolly. Let us also recognize that the grassroots membership of SID has continued to nourish the NSRT deliberations with practical insights, broadening the debate on many issues.

\section{Challenges addressed by the NSRT}

Mahbub ul Haq, who was the guiding spirit behind all NSRT initiatives, said at the last session of NSRT: 'In the world of ideas what is often lacking is intellectual courage, not wisdom.' Because of the uncommon courage of its leadership, all NSRT sessions have shown that courage by daring to challenge conventional thinking.

For instance:

- when there was a general hysteria in the mid1970s that the 'energy crisis' had been caused by the manipulations of the OPEC cartel, the energy roundtables of the NSRT had the courage to point out that the rise in energy prices was largely the natural result of long-term forces of demand and supply and that the world should get used to seeing the energy price fluctuate in future in response to economic forces;

- when there was a famine in several African countries in the 1980s, and global pre-occupation was with the supply of emergency food attempted to attract the attention of the policymakers towards a longer-term reordering of domestic development priorities in Africa, from cash crops to food crops, and suggested that no viable solution could be found without accelerated food production within Africa. This is conventional wisdom by now, though there were powerful institutional voices during the 1980s that Africa must continue to focus on the production of export crops;

- when a serious debt problem hit the developing world in the 1980s and when the World Bank/IMF and other financial institutions insisted on treating it on a case-by-case basis, the NSRT roundtables on money and finance kept reminding the world that it was a generalized problem to be dealt with on a global basis. This is now an accepted view;

- when the world community was still fascinated with economic growth models and when the human costs of structural adjustment were being ignored by the international financial institutions during the 1980s, the NSRT organized four major roundtables on human development, arguing that people must be placed at the centre of development, and that financial budgets must be balanced without unbalancing human lives;

- when the Uruguay Round of Multilateral Trade Negotiations was dominating the global scene in the 1980s and when the developing countries were still reluctant to include services and intellectual property rights within these talks, the NSRT roundtables on trade took the courageous position that a freer world trade order, including trade in services, was in the long-term interest of the poor nations. These trade roundtables played a key role in forging a consensus among influential policy-makers in trade negotiations;

- before there was a widespread recognition of increasing marginalization of the African continent and before the current concern about the slow disintegration of several African countries, the NSRT organized several roundtables on Africa which focused global attention on the neglected domestic and international development efforts in Africa and offered many concrete proposals for accelerating its economic and human progress; 


\section{Haq: Challenges to Development}

- more recently, when the global community was wrestling with new issues of global governance, the NSRT organized several roundtables on the restructuring of the UN system, including the Bretton Woods institutions, and advanced many concrete proposals - from the idea of an economic security council to convening a second Bretton Woods conference - which are likely to engage the attention of the international community for a long time to come.

\section{Looking ahead}

This is a time to look ahead, not to look back. The NSRT have decided that in the next phase of its evolution it should focus on one key theme for a few years so that all its policy dimensions are fully explored. It is in this spirit that we have chosen to concentrate on exploring 'A new framework of development co-operation' as the next NSRT intellectual challenge. This is a theme that brings together many other issues that are being debated on the global agenda such as the impact of globalization on the developing world; the emerging new economic relationships between the North and the South; the imperative of global human security in the face of continuing conflicts around the world; the need for new institutions of global governance; the challenging task of eliminating global poverty and advancing human development. Thus, the theme of a new development co-operation framework is a convenient but key entry point to address the urgent issues to usher in a just global society for the 21 st century.

\section{The challenge to rethink development co-operation}

The old framework of development co-operation was based on a vague and largely unimplemented commitment by the rich nations to provide 0.7 percent of their GNP in the form of concessional aid to the poor nations of the world to accelerate their pace of development. In actual practice, not even one-half of this aid commitment materialized. What was worse, a great deal of aid was mortgaged to the sordid realities of the Cold War - often channelled to strategic allies rather than to poor needy nations. Many commercial interests intruded, leading to an over-emphasis on large capital-intensive projects rather than small social sector programmes; preference for foreign consultants rather than national expertise; priority to physical capital rather than human capital; greater allocations through bilateral sources, sometimes tied to procurement in the country of origin, rather than through multilateral institutions. What is surprising is that, despite such limited assistance and despite such irrational allocations, so much good work was still done in so many nations. This only illustrates the enormous mileage the global community could have got had aid been more adequate and more rationally distributed.

There are many questions which are being raised about the future of development co-operation. For instance:

- has the framework of development dialogue between the North and the South changed substantially, focusing more on shared objectives that unite them rather than contentious issues that divide them? Should development co-operation become more focused on global objectives such as environment, population, drug control, poverty and human development rather than on interests of individual countries?

- are we now witnessing the slow withering away of the era of aid and the beginning of a much broader concept of development co-operation embracing trade, private investment, labour and financial flows? Should we base this new and broader framework of development co-operation on two-way compacts rather than on one-way transfers?

- how to forge a co-operation between rich and poor nations. For example, should there be a payment for global services rendered in the areas of pollution safeguards, control of diseases etc.? Are we on the threshold of a global taxation system?

- should aid continue in this new milieu and in what form? Should aid be focused only on the poorest regions and technical assistance be allocated mainly for domestic experts?

- how to face up to the much-needed restructuring and reinvention of all institutions of global 
governance, including the UN system and the Bretton Woods institutions.

These are the questions that the participants at the NSRT session addressed in June 1998. A few articles presented at that session are included here. NSRT will continue this discussion and will present its final report at its next session to be held in New York in September 2000.

\section{Reference}

Ward, B. (1980) Final Speech at the North-South Roundtable. Sussex, UK. 